\title{
Management of Phytophthora Crown Rot in Pumpkin and Zucchini Seedlings with Phosphonates
}

Camilla B. Yandoc-Ables, former Postdoctoral Research Associate, and Erin N. Rosskopf, Research Microbiologist, United States Horticultural Research Laboratory, United States Department of Agriculture-Agricultural Research Service, Fort Pierce, FL 34945; and Elizabeth M. Lamb, New York State Integrated Pest Management Program, Cornell University, Ithaca 14853

\begin{abstract}
Yandoc-Ables, C. B., Rosskopf, E. N., and Lamb, E. M. 2007. Management of Phytophthora crown rot in pumpkin and zucchini seedlings with phosphonates. Plant Dis. 91:1651-1656.

Experiments were conducted in the greenhouse to determine the efficacy of two phosphonatecontaining fungicides (FNX-100 and FNX-2500) against Phytophthora crown rot of pumpkin. The experiments were designed to determine the effects of crop cultivar, application method (soil drench versus foliar spray), and phosphonate concentration on the level of effectiveness of a crown rot management strategy using phosphonates. Pumpkin cultivar, treatment (type of fungicide product), phosphonate concentration, and application method significantly influenced the level of Phytophthora crown rot control. Between the two fungicides, only FNX-100 suppressed Phytophthora crown rot in pumpkin. For cv. Phantom, the highest level of control was achieved with the drench application of 3.0\% FNX-100 whereas, for cv. Spooktacular, all three concentrations of FNX-100 (1.0, 2.0, and 3.0\%, vol/vol) applied as a soil drench suppressed or significantly reduced the severity of crown rot. Additional experiments using zucchini as test plants demonstrated that, at the concentrations tested, FNX-100 was more efficacious than FNX-2500 in controlling Phytophthora crown rot and that zucchini cultivar or FNX-100 concentration did not significantly influence crown rot control with phosphonates. In this study, FNX-100, which is not currently labeled for use in vegetables, provided satisfactory disease control in both pumpkin and zucchini whereas FNX-2500, a foliar fungicide comprised of the phosphate/ phosphonates and copper, manganese, and zinc, did not significantly affect disease severity. This study, albeit limited in scope, showed that cultivar selection may play an important role in the successful management of Phytophthora crown rot on cucurbits with phosphonates, information which may be useful in designing additional tests and developing management strategies for pumpkin and zucchini that are grown in the field.
\end{abstract}

Phytophthora rot in cucurbits was first reported in the United States in the late 1930s $(23,38,39)$. The causal organism was identified as Phytophthora capsici Leonian, a species that attacks many other crops, including pepper (Capsicum spp.), tomato (Lycopersicon esculentum L.), and eggplant (Solanum melongena L.) $(15,36)$. $P$. capsici can cause seedling damping off, crown rot, stem lesions, foliar blight, leaf spots, and fruit rot. At present, there is no cucurbit cultivar with known resistance to this pathogen (3) and most of the cultivated species of cucurbits are susceptible

Corresponding author: E. N. Rosskopf E-mail: ERosskopf@ushrl.ars.usda.gov

Mention of a trademark, warranty, proprietary product, or vendor does not constitute a guarantee by the United States Department of Agriculture and does not imply its approval to the exclusion of other products or vendors that may also be suitable.

Accepted for publication 19 July 2007.

doi:10.1094/PDIS-91-12-1651

This article is in the public domain and not copyrightable. It may be freely reprinted with customary crediting of the source. The American Phytopathological Society, 2007. to $P$. capsici, with summer squash (Cucurbita pepo L.) as the most susceptible (17). In 1996, Gubler and Davis (17) reported that diseases caused by $P$. capsici have resulted in periodic losses in fields with heavy, poorly drained soils. Currently, however, there are reports of yearly losses due to this pathogen in all types of soil in the southeastern and northeastern United States and in other cucurbit-producing areas in the world $(2,19,20,24-26)$. Crop rotation has not been effective due to the pathogen's ability to persist in the soil for many years $(19,41)$ and to infect more than 50 plant species, including weeds $(15,16,36)$. Although fungicides can be a valuable component of a disease management program, there is no single fungicide that can provide high levels of efficacy, especially during periods of excessive soil moisture (6). Best management practices (BMPs) include water management, selection of well-drained areas for planting, and the application of fungicides.

Phosphorous acid and related compounds (i.e., phosphonates, phosphates, and phosphites) have been shown to be effective against several Phytophthora diseases, including late blight of potato (cause by $P$. infestans), avocado stem can- ker (caused by $P$. citricola), avocado root rot (caused by $P$. cinnamomi), Phytophthora canker in almond and cherry trees (caused by $P$. cambivora), and black pod disease of cocoa (caused by $P$. palmivora and $P$. megakarya) $(9,12,14,29,31,40)$. Suppression of disease caused by phosphorous acid has been attributed to the inhibition of oxidative phosphorylation in susceptible species of Oomycetes (27). There also was some evidence that phosphorous acid can induce natural defense mechanisms in plants. According to Rouhier et al. (33), exposure of $P$. capsici to phosphonates resulted in the production of watersoluble cell wall fractions, which, when applied to tobacco, stimulated the synthesis of capsidiol, a naturally produced antimicrobial compound.

Several field experiments have incorporated materials with phosphate or phosphoric and phosphorous acid active ingredients, similar to FNX-100 (BioPhos or Lexx-A-Phos) for evaluation against $P$. capsici in various crops, though few have included this specific product. Even fewer field experiments have been conducted evaluating these materials as stand-alone products. AgriFos400, a mixture of monoand dipotassium phosphite, applied alone multiple times throughout the growing season, provided control of Phytophthora blight of pumpkin, but during a relatively dry year (21). In another experiment in which multiple applications of Prophyt 4L were used, control of $P$. capsici in squash was comparable with other fungicide applications (10).

This study was conducted to evaluate the application of phosphonate-containing products as a means of managing Phytophthora crown rot in cucurbits, using pumpkin and zucchini seedlings grown under controlled greenhouse conditions. Additionally, this study was done to determine how crop cultivar, aside from phosphonate application method and concentration, can influence the effectiveness of a crown rot management approach that utilizes fungicides containing phosphonates.

\section{MATERIALS AND METHODS}

Pumpkin. The experimental design was a completely randomized four-way factorial. The experiment had five replications per cultivar, treatment, concentration, and 
application method combination and was repeated once. One replicate consisted of one plant per pot. To investigate whether disease control might be influenced by the type of cultivar, two commercially grown pumpkin cultivars were selected: a medium-sized fruit cultivar ("Phantom") and a small-sized fruit cultivar ("Spooktacular"). Seed of the cvs. Phantom and Spooktacular (Seminis Vegetable Seeds, Oxnard, CA) were pregerminated on wet paper towels incubated at $27^{\circ} \mathrm{C}$ in the dark for 3 days and then sown into plastic pots (5.5 by 5.5 by $5.0 \mathrm{~cm}$ ) containing greenhouse potting medium composed of sphagnum peat, processed pine bark, vermiculite, and perlite (Faffard 4P Mix; Faffard, Inc. Anderson, SC).

Plants were fertilized weekly beginning at the first-true-leaf stage with 20-20-20 fertilizer (Peter's Professional Water Soluble Fertilizer; Scotts-Sierra Horticultural Products Company, Marysville, $\mathrm{OH}$ ) and were watered regularly. Two experiments were conducted in a greenhouse, where temperature and humidity during the experimental period were approximately $24^{\circ} \mathrm{C}$ and $96 \%$, respectively.

Two products containing phosphonates were tested. FNX-100 (now commercially marketed as the fungicide Lexx-A-Phos and BioPhos) contains dipotassium phosphate $(22.67 \%)$ and dipotassium phosphonate $(20.40 \%)$ as active ingredients. FNX2500 is a foliar fungicide containing FNX100 plus equal amounts of zinc ( $\mathrm{Zn}$ ), copper $(\mathrm{Cu})$, and manganese $(\mathrm{Mn})$. Both were supplied by Foliar Nutrients, Inc., Cairo, GA. Each fungicide product was applied at three concentrations $(1.0,2.0$, and $3.0 \%$, $\mathrm{vol} / \mathrm{vol}$, in water) as a soil drench (50 $\mathrm{ml} /$ plant) and foliar spray (until incipient run-off, approximately $10 \mathrm{ml} /$ plant) at 7 days after sowing seed (one- to two-trueleaf stage). Each experiment included an uninoculated and an inoculated nofungicide control treatment for each cultivar. Controls consisted of five replications for each treatment and cultivar and a replicate consisted of a single plant. Uninoculated no-fungicide controls received $5 \mathrm{ml}$ of sterile deionized water.

Fungicide treatment plants and the inoculated control plants were inoculated with a 5-ml suspension of $P$. capsici zoospores containing approximately 4,000 zoospores $/ \mathrm{ml}$ at 5 days after the fungicides were applied. The zoospore production method used in the experiments was based on the procedure from Dah-Wu and Zentmyer (11). Fifteen 5-mm mycelial disks of $P$. capsici were obtained from 5-day-old

Table 1. Test statistics for the effects of cultivar, treatment, concentration, and application method on the severity of Phytophthora crown rot in pumpkin ${ }^{\mathrm{a}}$

\begin{tabular}{|c|c|c|c|c|}
\hline \multirow[b]{2}{*}{ Effect } & \multicolumn{4}{|c|}{ Analysis of variance-type statistics ${ }^{b}$} \\
\hline & $\mathbf{d f}_{\mathrm{N}}$ & $\mathbf{d f}_{\mathrm{D}}$ & $\mathbf{F}$ & $P$ value \\
\hline \multicolumn{5}{|l|}{ Experiment 1} \\
\hline Cultivar (V) & 1.0 & 28.6 & 48.73 & $<0.0001$ \\
\hline Treatment $(\mathrm{T})$ & 1.0 & 28.6 & 163.02 & $<0.0001$ \\
\hline $\mathrm{V} \times \mathrm{T}$ & 1.0 & 28.6 & 7.55 & 0.0103 \\
\hline Concentration $(\mathrm{C})$ & 1.85 & 28.6 & 7.09 & 0.0038 \\
\hline $\mathrm{V} \times \mathrm{C}$ & 1.85 & 28.6 & 5.87 & 0.0085 \\
\hline $\mathrm{T} \times \mathrm{C}$ & 1.85 & 28.6 & 1.75 & 0.1942 \\
\hline $\mathrm{V} \times \mathrm{T} \times \mathrm{C}$ & 1.85 & 28.6 & 1.68 & 0.2048 \\
\hline Application method (M) & 1.0 & 28.6 & 184.73 & $<0.0001$ \\
\hline $\mathrm{V} \times \mathrm{M}$ & 1.0 & 28.6 & 3.70 & 0.0643 \\
\hline $\mathrm{T} \times \mathrm{M}$ & 1.0 & 28.6 & 119.29 & $<0.0001$ \\
\hline $\mathrm{V} \times \mathrm{T} \times \mathrm{M}$ & 1.0 & 28.6 & 21.11 & $<0.0001$ \\
\hline $\mathrm{C} \times \mathrm{M}$ & 1.85 & 28.6 & 0.45 & 0.6293 \\
\hline $\mathrm{V} \times \mathrm{C} \times \mathrm{M}$ & 1.85 & 28.6 & 0.23 & 0.7813 \\
\hline $\mathrm{T} \times \mathrm{C} \times \mathrm{M}$ & 1.85 & 28.6 & 6.16 & 0.0070 \\
\hline $\mathrm{V} \times \mathrm{T} \times \mathrm{C} \times \mathrm{M}$ & 1.85 & 28.6 & 7.03 & 0.0040 \\
\hline \multicolumn{5}{|l|}{ Experiment 2} \\
\hline Cultivar (V) & 1.0 & 33.9 & 75.31 & $<0.0001$ \\
\hline Treatment $(\mathrm{T})$ & 1.0 & 33.9 & 53.95 & $<0.0001$ \\
\hline $\mathrm{V} \times \mathrm{T}$ & 1.0 & 33.9 & 11.35 & 0.0019 \\
\hline Concentration $(\mathrm{C})$ & 2.0 & 33.9 & 7.60 & 0.0019 \\
\hline $\mathrm{V} \times \mathrm{C}$ & 2.0 & 33.9 & 1.58 & 0.2198 \\
\hline $\mathrm{T} \times \mathrm{C}$ & 2.0 & 33.9 & 3.38 & 0.0459 \\
\hline $\mathrm{V} \times \mathrm{T} \times \mathrm{C}$ & 2.0 & 33.9 & 4.71 & 0.0157 \\
\hline Application method (M) & 1.0 & 33.9 & 48.6 & $<0.0001$ \\
\hline $\mathrm{V} \times \mathrm{M}$ & 1.0 & 33.9 & 8.75 & 0.0056 \\
\hline $\mathrm{T} \times \mathrm{M}$ & 1.0 & 33.9 & 23.76 & $<0.0001$ \\
\hline $\mathrm{V} \times \mathrm{T} \times \mathrm{M}$ & 1.0 & 33.9 & 0.81 & 0.3748 \\
\hline $\mathrm{C} \times \mathrm{M}$ & 2.0 & 33.9 & 4.4 & 0.0200 \\
\hline $\mathrm{V} \times \mathrm{C} \times \mathrm{M}$ & 2.0 & 33.9 & 3.62 & 0.0378 \\
\hline $\mathrm{T} \times \mathrm{C} \times \mathrm{M}$ & 2.0 & 33.8 & 1.74 & 0.1908 \\
\hline $\mathrm{V} \times \mathrm{T} \times \mathrm{C} \times \mathrm{M}$ & 2.0 & 33.8 & 7.21 & 0.0025 \\
\hline
\end{tabular}

${ }^{a}$ Pumpkin cultivars used were Phantom and Spooktacular; treatments were FNX-100 and FNX-2500; concentrations tested were 1.0, 2.0, and 3.0\%; application methods were soil drench and foliar spray. Disease severity was assessed at 21 days after inoculation.

${ }^{b}$ Abbreviations: $\mathrm{df}_{\mathrm{N}}=$ numerator degrees of freedom and $\mathrm{df}_{\mathrm{D}}=$ denominator degrees of freedom.

cultures on PARP/V8 juice agar $(250 \mathrm{ml}$ of clarified V8 juice, $3 \mathrm{~g}$ of $\mathrm{CaCO}_{3}$, and 750 $\mathrm{ml}$ of water) and transferred to petri dishes (90 by $15 \mathrm{~mm}$ ) containing $20 \mathrm{ml}$ of quarter-strength V8 juice. The disks in petri dishes were incubated at $27^{\circ} \mathrm{C}$ in the dark for $48 \mathrm{~h}$, after which they were rinsed with sterile water four times to remove the V8 juice. After the disks had been rinsed, 20 $\mathrm{ml}$ of $10^{-4} \mathrm{M}$ 2(N-morpholinolethanesulfonic acid) (MES) solution was added to each of the plates. The plates then were incubated for $48 \mathrm{~h}$ inside a $25^{\circ} \mathrm{C}$ incubator with continuous light. After the incubation period, the zoospore suspension was filtered through two layers of cheesecloth and calibrated with the aid of a hemacytometer.

Zucchini. Based on the results from the experiments on pumpkin, an experiment was designed to investigate the effects of cultivar, treatment (FNX-100 versus FNX2500), and product concentration (1.0, 2.0, and $3.0 \%$, vol/vol, in water) on the suppression of Phytophthora crown rot in zucchini ( $C$. pepo L.). Two experiments were carried out to compare the efficacy of three concentrations of the two phosphonate-containing products applied as soil drenches. Methods were the same as those used for the pumpkin experiment.

In the first experiment, two cultivars were compared: PI508469, a zucchini line from Korea (obtained from the United States Department of Agriculture NorthCentral Regional Plant Introduction Station, Ames, IA) and Senator, a commercial cultivar from Seminis Vegetable Seed Co. In the second experiment, the line PI 615115 (from Vermont) was used in place of PI508469 due to a limited supply of seed of the first line. Both lines (PI615115 and PI508469) were chosen based on the results from a study by Goldy and Francis (2001; unpublished data available at http://www.hort.purdue.edu/hort/ext/veg/M WVVT2001/html/PHYTOPHTHORA $\% 20$ SQUASH.htm) where they screened 33 summer squash lines for their tolerance to $P$. capsici. These two lines were reportedly two of the eight best-performing lines collected from eight countries and were reported to have a similar level of tolerance against $P$. capsici.

Disease severity was observed and assessed at 21 days after inoculation using a rating scale of 0 to 5 that is based on aboveground symptoms of disease, with 0 $=$ no disease, $1=$ discoloration of the crown, 2 = discoloration + constriction (lesion) of the crown, $3=$ crown lesion + wilting of lower leaves, $4=$ crown lesion + wilting of most leaves or severely rotten stem, and $5=$ death. Ordinal data from 21 days post inoculation were analyzed according to a nonparametric method described by Shah and Madden (34). The inoculated and noninoculated control treatments were not included in the data analysis. The relative treatment effects and 
their confidence intervals were calculated using the LD_CI macro by Brunner et al. (5). The relative treatment effect, which is a function of the mean rank, is the quantity that represents the probability that one random variable is greater than the other.

\section{RESULTS}

Pumpkin. In both experiments, interactions among cultivar (Phantom versus Spooktacular), treatment (FNX-100 versus FNX-2500), application method (drench versus foliar), and concentration (1.0, 2.0, and $3.0 \%)$ were significant $(P=0.01$; Table 1 ). In experiment 1 , the disease was effectively controlled in cv. Phantom by all three concentrations of FNX-100 applied as a drench (Table 2; Fig. 1A). For cv. Spooktacular, disease was controlled by the drench application of 2.0 and $3.0 \%$ FNX-100 (Table 2; Fig. 1B). All of the other treatment, application method, and concentration combinations did not suppress disease, with disease severity ranging from 1 (stem lesion) to 5 (death).

In experiment 2, however, disease in Phantom was controlled only by the highest concentration of FNX-100 (3.0\%) applied as a drench (Fig. 2A) whereas disease in Spooktacular was controlled by all three concentrations of FNX-100 applied as drenches (Fig. 2B). All of the other treatment, method, and concentration combinations did not control the disease, with severity ranging from 4 (stem lesion, defoliation, and severe wilting) to 5 (death). FNX-2500, at any concentration, applied as a soil drench or as a foliar spray, did not suppress disease. FNX-100 consistently provided control of crown rot in Phantom when applied as a $3.0 \%$ soil drench. For Spooktacular, all three concentrations of FNX-100 applied as a soil drench effectively controlled crown rot. The relative treatment effects were used to compare the severity of rot among all the cultivar, treatment, concentration, and application method combinations. The median crown rot severity ratings for both cultivars for two experiments are given in Table 2. Uninoculated controls showed no disease in either cultivar in either experiment. All inoculated no-fungicide control plants of both cultivars in both experiments were completely dead (disease severity rating of 5) by 21 days after inoculation.

Zucchini. For both experiments, there was a significant treatment effect $(P=$ 0.01 ). Other factors (cultivar and concentration) did not have an effect on the level of disease (Table 3). All plants treated with FNX-100, regardless of cultivar and FNX100 concentration, had significantly lower disease ratings compared with plants that received soil drenches of FNX-2500 solutions. Unlike the pumpkin experiment, there was no interaction between the cultivar, the treatment, and the concentration. Application of FNX-100 at 1.0 to $3.0 \%$ concentration resulted in disease suppres-
Table 2. Median disease severity ratings for Phytophthora crown rot of pumpkin in response to the application of phosphonates ${ }^{\mathrm{a}}$

\begin{tabular}{lccccc}
\hline & \multicolumn{4}{c}{ Pumpkin cultivar } \\
\cline { 2 - 3 } & \multicolumn{2}{c}{ Phantom } & & \multicolumn{2}{c}{ Spooktacular } \\
\cline { 2 - 3 } \cline { 5 - 6 } Treatment, method, concentration & Exp. 1 & Exp. 2 & & Exp. 1 & Exp. 2 \\
\hline FNX-100, drench, 1\% & 0 & 5.0 & & 1.0 & 0 \\
FNX-100, drench, 2\% & 0 & 5.0 & & 0 & 0 \\
FNX-100, drench, 3\% & 0 & 0 & & 0 & 0 \\
FNX-100, foliar, 1\% & 5.0 & 5.0 & & 5.0 & 5.0 \\
FNX-100, foliar, 2\% & 5.0 & 5.0 & & 2.0 & 5.0 \\
FNX-100, foliar, 3\% & 5.0 & 5.0 & & 2.0 & 4.0 \\
FNX-2500, drench, 1\% & 5.0 & 5.0 & & 5.0 & 5.0 \\
FNX-2500, drench, 2\% & 5.0 & 5.0 & & 3.0 & 5.0 \\
FNX-2500, drench, 3\% & 5.0 & 5.0 & & 4.0 & 5.0 \\
FNX-2500, foliar, 1\% & 5.0 & 5.0 & & 5.0 & 4.0 \\
FNX-2500, foliar, 2\% & 5.0 & 5.0 & & 5.0 & 5.0 \\
FNX-2500, foliar, 3\% & 5.0 & 5.0 & & 1.0 & 5.0 \\
Inoculated untreated control & 5.0 & 5.0 & & 5.0 & 5.0 \\
\hline
\end{tabular}

${ }^{a}$ Results from two experiments are given for each of the cultivars tested. Rating scale: $0=$ no disease, $1=$ discoloration at the base, $2=$ discoloration + constriction (lesion), $3=$ lesion + lower leaves wilted, $4=$ lesion + wilting of most leaves or severely rotten stem, and $5=$ dead.

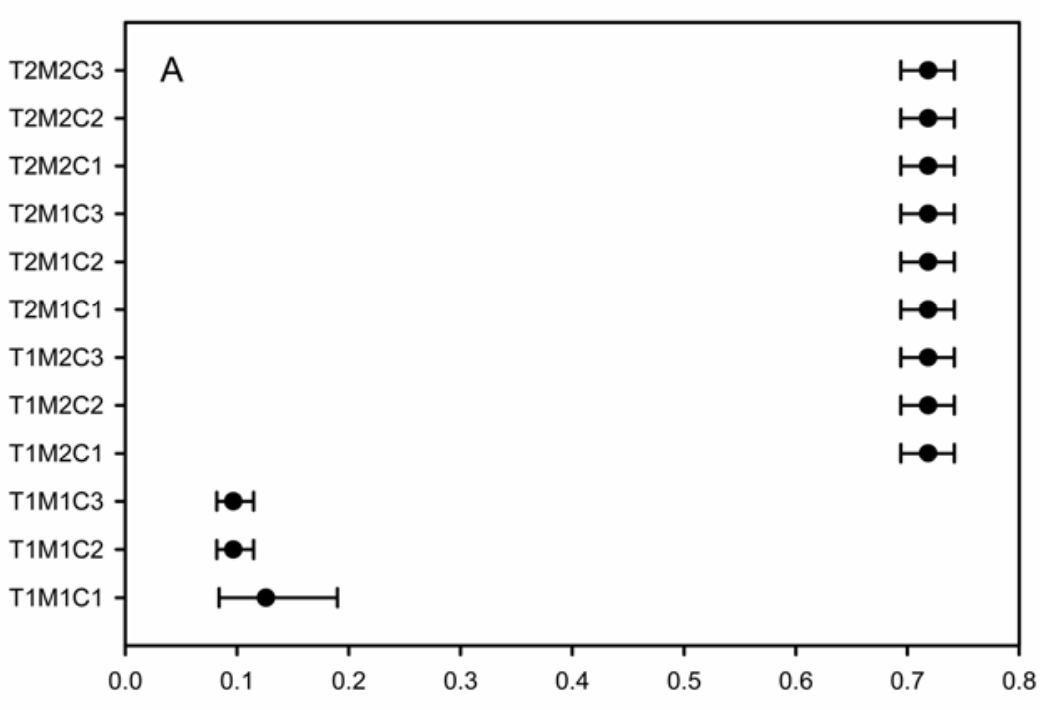

Relative treatment effect

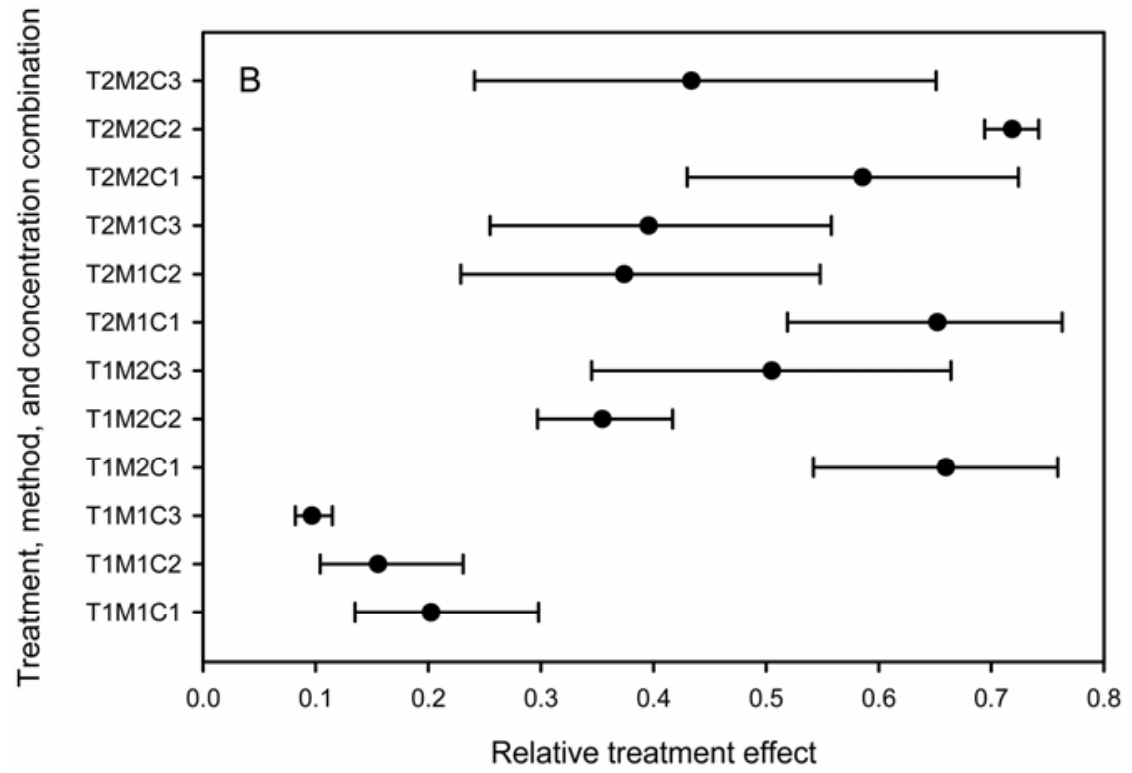

Fig. 1. Relative effect of each treatment $(\mathrm{T} 1=\mathrm{FNX}-100$ and $\mathrm{T} 2=\mathrm{FNX}-2500)$, application method $(\mathrm{M} 1=$ drench and $\mathrm{M} 2=$ foliar $)$, and concentration $(\mathrm{C} 1=1.0 \%, \mathrm{C} 2=2.0 \%$, and $\mathrm{C} 3=3.0 \%)$ combination on the severity of Phytophthora crown rot in pumpkin cultivars A, Phantom and B, Spooktacular in experiment 1. Error bars are based on the $95 \%$ confidence intervals. 

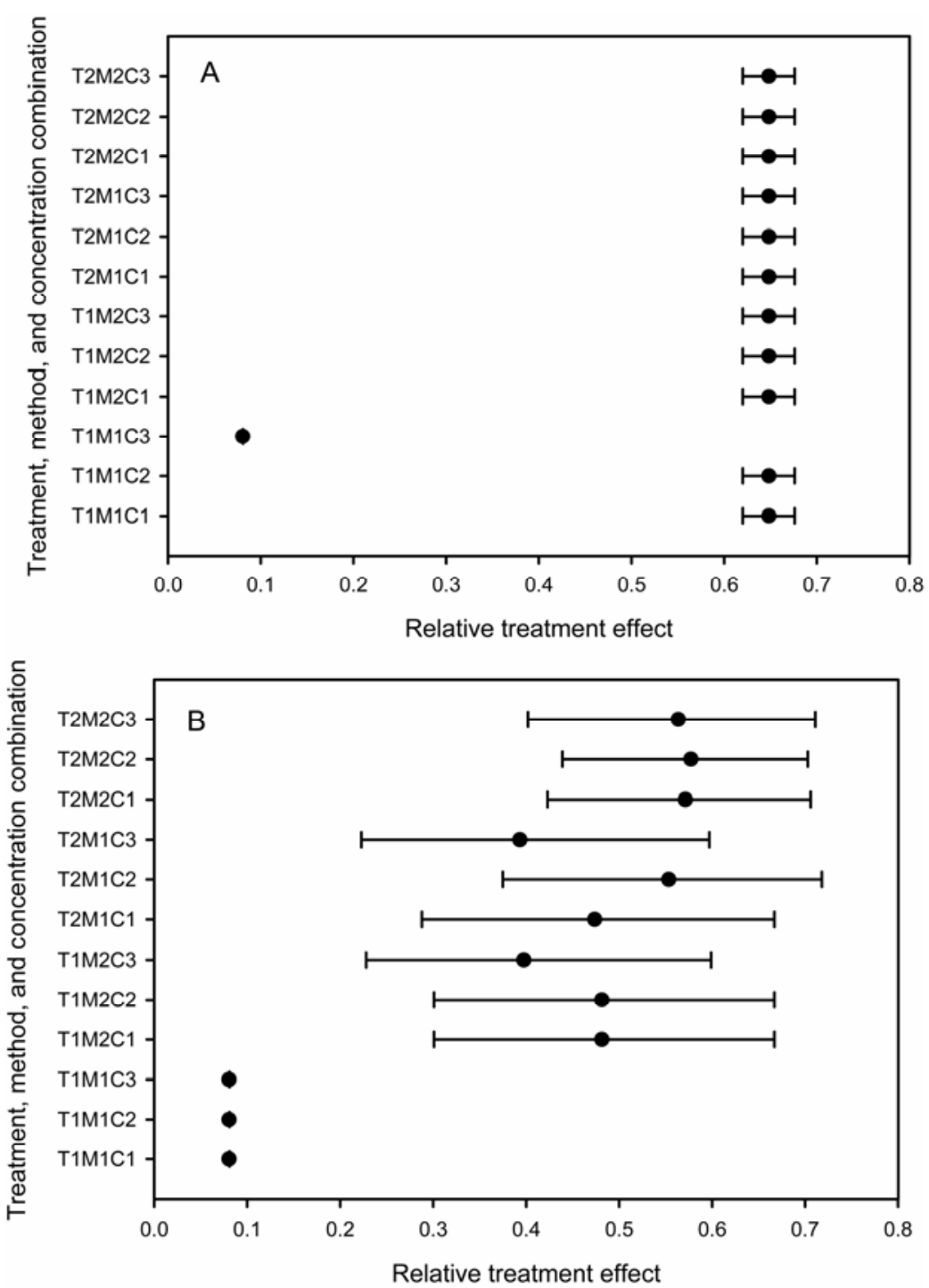

Fig. 2. Relative effect of each treatment $(\mathrm{T} 1=\mathrm{FNX}-100$ and $\mathrm{T} 2=\mathrm{FNX}-2500)$, application method $(\mathrm{M} 1=$ drench and $\mathrm{M} 2=$ foliar $)$, and concentration $(\mathrm{C} 1=1.0 \%, \mathrm{C} 2=2.0 \%$, and $\mathrm{C} 3=3.0 \%)$ combination on the severity of Phytophthora crown rot in pumpkin cultivars A, Phantom and $\mathbf{B}$, Spooktacular in experiment 2. Error bars are based on the $95 \%$ confidence intervals.

Table 3. Test statistics for the effects of cultivar, treatment, and concentration on the severity of Phytophthora crown rot in zucchini ${ }^{\mathrm{a}}$

\begin{tabular}{lrrrr}
\hline & \multicolumn{4}{c}{ Analysis of variance-type statistics } \\
\cline { 2 - 5 } Effect & $\mathbf{d f}_{\mathbf{N}}$ & $\mathbf{d f}_{\mathbf{D}}$ & $\mathbf{F}$ & $\boldsymbol{P}_{\text {value }}$ \\
\hline Experiment 1 & & & & \\
$\quad$ Cultivar (V) & 1.0 & 11.7 & 3.05 & 0.1069 \\
Treatment (T) & 1.0 & 11.7 & 322.61 & $<0.0001$ \\
V $\times$ T & 1.0 & 11.7 & 0.09 & 0.7681 \\
Concentration (C) & 1.0 & 11.7 & 0.94 & 0.3515 \\
V $\times$ C & 1.0 & 11.7 & 3.05 & 0.1069 \\
T $\times$ C & 1.0 & 11.7 & 5.83 & 0.0331 \\
V $\times$ T $\times$ C & 1.0 & 11.7 & 0.09 & 0.7681 \\
Experiment 2 & & & & \\
Cultivar (V) & 1.0 & 7.0 & 0.02 & 0.9034 \\
Treatment (T) & 1.0 & 7.0 & 474.85 & $<0.0001$ \\
V $\times$ T & 1.0 & 7.0 & 0.02 & 0.9034 \\
Concentration (C) & 1.0 & 7.0 & 2.86 & 0.1346 \\
V $\times$ C & 1.0 & 7.0 & 0.02 & 0.9034 \\
T $\times$ C & 1.0 & 7.0 & 2.86 & 0.1346 \\
V $\times$ T $\times$ C & 1.0 & 7.0 & 0.02 & 0.9034 \\
\hline
\end{tabular}

${ }^{a}$ Zucchini cultivars used were PI508469 (from Korea) and Senator for experiment 1 and PI615115 (from Vermont) and Senator for experiment 2; treatments were FNX-100 and FNX-2500 (applied as soil drench); concentrations tested were 1.0, 2.0, and 3.0\%. Disease severity was assessed at 21 days after inoculation. Untreated controls were not included in the statistical analysis.

${ }^{b}$ Abbreviations: $\mathrm{df}_{\mathrm{N}}=$ numerator degrees of freedom and $\mathrm{df}_{\mathrm{D}}=$ denominator degrees of freedom. sion (Fig. 3A and B). Uninoculated controls showed no disease in either cultivar in either experiment. All inoculated nofungicide control plants of both cultivars in both experiments were completely dead (disease severity rating of 5) by 21 days after inoculation.

\section{DISCUSSION}

The effectiveness of phosphate-based materials against Phytophthora diseases, whether as a foliar spray or as a soil drench, has been evaluated by several investigators in past years. Phosphonates applied as foliar spray or as a soil drench has been shown to inhibit $P$. cambivora infection in almond and cherry trees (40) and P. cinnamomi infection in pine (Pinus radiata) seedlings (1). Foliar application of phosphonates has been shown to reduce disease incidence or severity of Phytophthora rot in papaya (37) and tuber rot in potato (8). However, some studies have shown that application of phosphorous acid or related compounds may not always be effective in controlling Phytophthora spp. Possible reasons for variable efficacy include differences in the uptake and translocation by different crop species, application rate, timing of application, and environmental factors $(7,8)$.

In this study, Phytophthora crown rot in young pumpkin and zucchini plants was consistently controlled, without any observable phytotoxic damage, only when the phosphate/phosphonate material was applied as a soil drench. Drench application of phosphonates, compared with foliar application, has been shown to provide better control of Phytophthora root rot of azalea (Rhododendron ponticum cv. Brides Bouquet), Victorian laceflower (Thryptomene calycina (Lindl.) Stapf) and petunia (Petunia $\times$ hybrida Hort. ex Vilm.) (13). Although the mechanism of disease suppression through the foliar application of phosphonates is not yet well understood, it appears that the efficacy of foliar application is influenced by the ability of the plant leaves to absorb, transport, and metabolize phosphonates more efficiently, which can vary from species to species. In weeds, it has been demonstrated that differential absorption influenced the level of sensitivity or tolerance to certain foliar-applied herbicides $(28,32,35)$.

The drench application of FNX-100 at all concentrations we tested was effective in controlling disease in young zucchini plants, regardless of cultivar. However, in pumpkin, crop cultivar had a significant influence on the level of disease suppression. Although it is not known whether cvs. Phantom and Spooktacular are equally susceptible to Phytophthora crown rot in the field, in this study, Phantom required a greater amount of material for suppression of this disease. The inoculated plants receiving no fungicide treatment were completely killed by the pathogen by 21 days 
after inoculation, regardless of the cultivar. Although the zucchini lines that were used in the study were selected based on having shown tolerance to Phytophthora capsici in the field, those differences were not seen in this study. The finding that different concentrations of the phosphonates were needed to effectively control crown rot in Phantom and Spooktacular indicates that the type of cultivar should be one of the main considerations when devising crown rot management protocols that involve phosphonate-containing materials, even though these cultivars showed no significant difference in susceptibility to the pathogen when applied without fungi- cide. The influence of cultivar on the amount of phosphorous acid required to control late blight tuber rot also has been reported by Johnson et al. (22). In their study, the resistant cv. Umatilla Russet required less frequent application of phosphorus acid than the susceptible cv. Ranger Russet (22).

The fungicide FNX-2500 contains minimal amounts (less than $1 \%$ ) of dipotassium phosphate and dipotassium phosphonate; it also contains equal amounts of the micronutrients $\mathrm{Cu}, \mathrm{Mn}$, and $\mathrm{Zn}$, which are required (at different amounts) for normal plant growth. Due to possible toxicity effects, the concentrations tested were
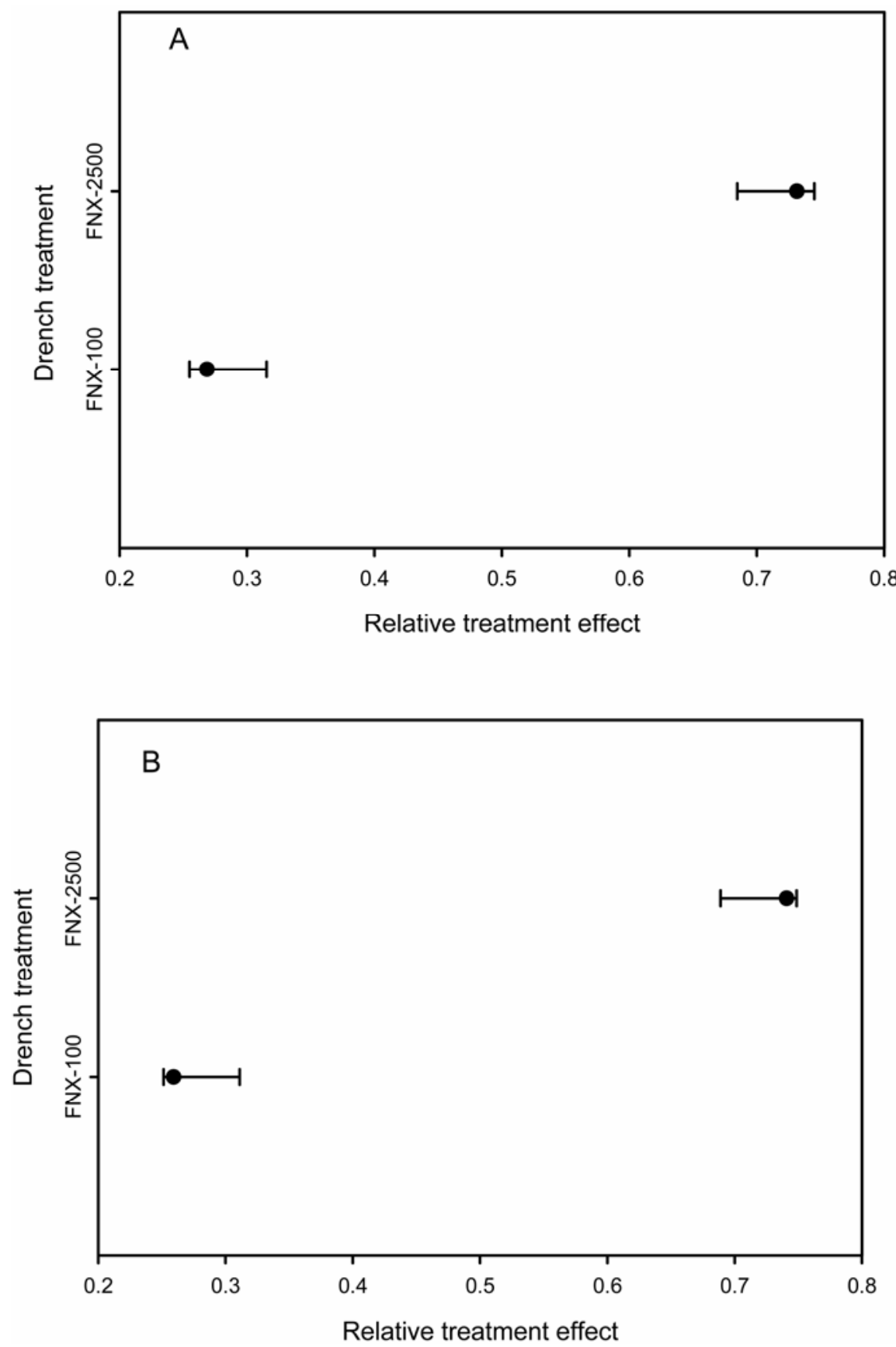

Fig. 3. Relative effect of FNX-100 and FNX-2500 drenches on the severity of Phytophthora crown rot in zucchini cvs. Korean, Senator, and Vermont in experiments A, 1 and B, 2. Error bars are based on the $95 \%$ confidence intervals. based primarily on the amounts of $\mathrm{Cu}, \mathrm{Mn}$, and $\mathrm{Zn}$ in the product. However, the application of FNX-2500 at the concentrations that did not cause toxicity from its micronutrient component did not translate to the suppression of Phytophthora crown rot by the amounts of phosphonates it contained. Hence, at the concentrations we tested in this study, there appears to be no benefit from using the mixtures of the low percentage of phosphonates, $\mathrm{Cu}, \mathrm{Mn}$, and $\mathrm{Zn}$ in suppressing Phytophthora crown rot in young pumpkin and zucchini plants. This formulation, with the chelated $\mathrm{Cu}$ component, may provide greater benefit for control of foliar bacterial diseases.

Better and more consistent control with higher concentrations of dipotassium phosphonate and dipotassium phosphate also may be due partly to the sensitivity of $P$. capsici to these materials. According to a study by Ouimette and Coffey (30), species of Phytophthora varied in their sensitivity to potassium phosphonate, with $P$. capsici among the least sensitive of those species that they tested. However, in this study, in zucchini, $P$. capsici infection was suppressed by FNX-100 at all concentrations tested. Perhaps this is due to the differences in the uptake, translocation, and metabolism of phosphonates by pumpkin and zucchini (8). It is believed that the application of phosphonates can stimulate host plant defense responses in addition to having direct fungicidal effects, thus protecting the plant from pathogen attack (18). Although this study was done as a small-scale greenhouse experiment, with few cultivars, the results that we obtained provide further evidence that crops or cultivars may vary in the amount of phosphonates that they require to stimulate their defense systems. This study provides information on the efficacy of various concentrations and application methods for FNX-100 and FNX-2500, which can serve as guidelines for designing large-scale disease management studies in the field, where $P$. capsici also infects foliage and fruit. Based on the results of this study, the treatment recommended for evaluation in a field study is FNX-100 applied at 3\% as a soil drench. Multiple applications are anticipated to be needed to obtain full-season control.

\section{ACKNOWLEDGMENTS}

This project was supported in part by a grant from the IR-4 Southern Region Biopesticide Program. We thank K. Rotindo, J. Smith, B. Stange, and J. Taylor for their technical assistance; and D. Shah for statistical guidance.

\section{LITERATURE CITED}

1. Ali, Z., Smith, I., and Guest, G. I. 1999. Effect of potassium phosphonates on root rot of Pinus radiata caused by Phytophthora cinnamomi. Australas. Plant Pathol. 28:120-125.

2. Babadoost, M. 2000. Outbreak of Phytophthora foliar blight and fruit rot in processing pumpkin fields in Illinois. Plant Dis. $84: 1345$.

3. Babadoost, M. 2004. Phytophthora Blight: A 
Serious Threat to Cucurbit Industries. American Phytopathological Society Feature Article http://apsnet.org/online/feature/cucurbit/

4. Babadoost, M., and Islam, S. Z. 2003. Fungicide seed treatment effects on seedling damping-off of pumpkin caused by Phytophthora capsici. Plant Dis. 87:63-68.

5. Brunner, E., Domhof, S., and Langer, F. 2002. Nonparametric Analysis of Longitudinal Data in Factorial Experiments. John Wiley \& Sons, New York.

6. Café-Filho, A. C., Duniway, J. M., and Davis, R. M. 1995. Effects of frequency of furrow irrigation on root and fruit rots of squash caused by Phytophthora capsici. Plant Dis. 79(1):4448

7. Cooke, L. R., and Little, G. 1996. Foliar application of phosphonates formulations for the control of potato tuber blight. Brighton Crop Prot. Conf. Pests Dis. 1:263-268.

8. Cooke L. R., and Little, G. 2001. The effect of foliar application of phosphonates formulations on the susceptibility of potato tubers to late blight. Pest Manage. Sci. 58:17-25.

9. Cooke, L. R., and Little, G. 2002. The effect of foliar application of phosphonate formulations on the susceptibility of potato tubers to late blight. Pest Manage. Sci. 58 (1):17-25.

10. Csinos, A. S., Hickman, L. L., and Hargett, U. 2006. Evaluation of fungicides for management of Phytophthora capsici applied through drip irrigation, 2005. Fungic. Nematicide Tests 61:V053.

11. Dah-Wu C., and Zentmyer, G. A. 1970. Production of sporangia by Phytophthora cinna$m o m i$ in axenic culture. Mycologia 62:398402

12. Darvas, J. M., Toriem, J. C., and Milne, D. L. 1984. Control of avocado root rot by trunk injection with phosethyl-Al. Plant Dis. 68:691693.

13. DeBoer R. F., and Greenhalgh, F. C. 1990. Efficacy of potassium phopshonate in controlling Phytophthora root rot of subterranean clover and ornamental plants in Victoria. Australas. Plant Pathol. 19:124-125.

14. El-Hamawi, Z. A., Menge, J. A., and Adams, C. J. 1995. Methods of fosetyl-Al application and phosphonate levels in avocado tissue needed to control stem canker caused by Phytophthora citricola. Plant Dis. 79(8):770778.

15. Erwin, D. C., and Ribiero, O. K. 1996. Pages 262-268 in: Phytophthora Diseases Worldwide. American Phytopathological Society, St. Paul, $\mathrm{MN}$
16. French-Monar, R. D., Jones, J. B., and Roberts, P. D. 2006. Characterization of Phytophthora capsici associated with roots of weeds on Florida vegetable farms. Plant Dis. 90:345-350.

17. Gubler, W. D., and Davis, R. M. 1996. Phytophthora Crown and Root Rot. Pages 19-20 in: Compendium of Cucurbit Diseases. T. A. Zitter, D. L. Hopkins, and C. E. Thomas, eds. American Phytopathological Society Press, St. Paul, MN.

18. Guest, D., and Bompeix, G. 1990. The complex mode of action of phosphonates. Australas. Plant Pathol. 19:113-114.

19. Hausbeck, M. 2004. Phytophthora lessons learned: irrigation water and snap beans. Veg. Grow. News 38:2829.

20. Holmes, G. J., Lancaster, M. E., Rodriguez, R. J., and Redman, R. S. 2001. Relative susceptibility of cucurbit and Solanaceous crops to Phytophthora blight. (Abstr.) Phytopathology 91:S39.

21. Islam, S. Z., and Babadoost, M. 2004. Evaluation of selected fungicides for control of Phytophthora blight in processing pumpkin, 2003. Fungic. Nematicide Tests 59:V129.

22. Johnson, D. A., Inglis, D. A., and Miller, J. S. 2004. Control of potato tuber rots caused by Oomycetes with foliar applications of phosphorous acid. Plant Dis. 88:1153-1159.

23. Kreutzer, W. A. 1937. A Phytophthora rot of cucumber fruit. (Abstr.) Phytopathology 27:955.

24. Latin, R. X., and Rane, K. 1999. Identification and Management of Pumpkin Diseases. Purdue University, BP-17.

25. Lee, B. K., Kim, B. S., Chang, S. W., and Hwany, B. K. 2001. Aggressiveness of isolates of Phytophthora capsici from pumpkin and pepper. Plant Dis. 85:797-800.

26. McGrath, M. T. 2001. Phytophthora Blight of Cucurbits. http://vegetablemdonline.ppath. cornell.edu/factsheets/Cucurbit_Phytoph2.htm (accessed August 2006).

27. McGrath, M. T. 2004. What are Fungicides? The Plant Health Instructor. DOI: 10.1094/ PHI-I-2004-0825-01. http://www.apsnet.org/ education/IntroPlantPath/Topics/fungicides.pdfs/

28. Mersey, B. G., Hall, J. C., Anderson, D. M., and Swanton, C. J. 1990. Factors affecting the herbicidal activity of glufosinate-ammonium: absorption, translocation, and metabolism in barley and green foxtail. Pestic. Biochem. Physiol. 37:90-98.

29. Opoku, I. Y., Akrofi, A. Y., Apiah, A. A., and Luterbacher, M. C. 1998. Trunk injection of phosphonate for the control of black pod disease of cocoa. Trop. Sci. 38:179-185.

30. Ouimette, D. G., and Coffey, M. D. 1989. Comparative antifungal activity of four phosphonate compounds against isolates of nine Phytophthora species. Phytopathology 79:761767.

31. Pegg, K. G., Whiley, A. W., Saranah, J. B., and Glass, R. J. 1985. Control of Phytophthora root rot of avocado with phosphorous acid. Australas. Plant Pathol. 14(2):25-29.

32. Ridley, S. M. and McNally, S. F. 1985. Effects of phosphinothricin on the isoenzymes of glutamine synthetase isolated from the plant species which exhibit varying degrees of susceptibility to the herbicide. Plant Sci. 39:3136

33. Rouhier, P. H., Bruneteau, M., Pivot, V., Bompeix, G., and Michel, G. 1993. Effect of phosphonate on the composition of the mycelial wall of Phytophthora capsici. Phytochemistry 32(6):1407-1410.

34. Shah, D. A., and Madden, L. V. 2004. Nonparametric analysis of ordinal data in designed factorial experiments. Phytopathology 94(1) 33-43.

35. Steckel, G. J., Hart, S. E., and Wax, L. M. 1997. Absorption and translocation of glufosinate on four weed species. Weed Sci. 45:378 381.

36. Tian, D., and Babadoost, M. 2004. Host range of Phytophthora capsici from pumpkin and pathogenicity of isolates. Plant Dis. 88:485489.

37. Vawdrey, L. L., Grice, K. E., Peterson, R. A. and DeFaveri, J. 2004. The use of metalaxyl and potassium phosphonates, mounds, and organic and plastic mulches, for the management of Phytophthora root rot of papaya in far northern Queensland. Australas. Plant Pathol 33:103-107.

38. Waint, J. S. 1939. Species of Phytophthora responsible for market decay of western honeydew melons and cantaloupes. Plant Dis. Rep. 23:322.

39. Waint, J. S., and Tucker, C.M. 1940. A rot of Winter Queen watermelon caused by Phy tophthora capsici. J. Agric. Res. 60:73-88.

40. Wicks, T. J., and Hall, B. 1990. Control of Phytophthora canker with phosphonates in artificially inoculated almond and cherry trees. Aust. J. Exp. Agric. 30:413-420.

41. Zitter, T. A., Hopkins, D. L., and Thomas, C. E., eds. 1996. Compendium of Cucurbit Diseases. American Phytopathological Society, St. Paul, MN. 